\title{
Maria Edgeworth's The Double Disguise: Language Development, Experimentation, and the Importance of Juvenilia
}

\author{
Ryan Twomey \\ Macquaire University, Australia
}

Copyright (c) 2019 by Ryan Twomey. This text may be archived and redistributed both in electronic form and in hard copy, provided that the author and journal are properly cited and no fee is charged for access.

\begin{abstract}
Maria Edgeworth is well known for her didactic tales and her production of regionally accurate narratives. Much less is known, however, about her juvenilia and the influence this writing had on her adult work. In the following article, I examine numerous words identifiable in Maria Edgeworth's juvenilia drama, The Double Disguise (1786), which antedate the Oxford English Dictionary (OED) quotations attributed to her adult work. Through examining the similarities in word choices and vocabulary between The Double Disguise and her later work, this article argues for the importance of juvenilia on the development of Edgeworth's adult authorship.
\end{abstract}

Key Words. Maria Edgeworth, Juvenilia, Oxford English Dictionary, OED, Irish English, The Double Disguise, Castle Rackrent.

Resumen. Maria Edgeworth es bien conocida por ser la autora de cuentos didácticos y de narraciones de marcado carácter regional. Existe un apartado de su producción literaria, sin embargo, que es mucho menos conocido. En el presente artículo se analizan numerosos términos que se pueden identificar en el drama temprano The Double Disguise (1786) escrito por la autora. Dichos términos anteceden a las citas que aparecen en el Oxford English Dictionary (OED) y que se atribuyen a la escritura de Edgeworth de la época de madurez. A través del estudio de las similitudes en el uso del vocabulario entre The Double Disguise y las obras posteriores de Edgeworth, se quiere destacar la importancia de la obra temprana en el desarrollo de la literatura escrita por Edgeworth.

Palabras clave. Maria Edgeworth, obra temprana, Oxford English Dictonary, ingles hablado en Irlanda, The Double Disguise, Castle Rackrent. 
In an address to the Philological Society in 1887, James Murray, the Oxford English Dictionary's primary editor from 1879 till his death in 1915, outlined the difficulty of collating the evidential quotations provided by the $O E D$. He stated:

You sort your quotations into bundles on your big table, and think you are getting the word's pedigree right, when a new sense, or three of four new senses, start up, which upset all your scheme, and you are obliged to begin afresh, often three or four times. (Brewer, "Treatment" 212)

The quotations provided by the $O E D$ are, in Murray's own words, "the essence of the work". It is from the quotations, the real-world usage, that definitions are derived. The quotations in the $O E D$ are "the basis of its claim to scholarly and historical authority" and "play a crucial role in ... identifying the authorised users of the language and the connotations and nuances of the way words are actually used ... " (Brewer, "Role of Quotations"). In other words it is from these quotations that the history and development of the English language is discernible - what the $O E D$ has labelled, "The definitive record of the English language".

This article examines a selection of individual words identifiable in Maria Edgeworth's juvenilia drama, The Double Disguise (1786), which antedate the Oxford English Dictionary $(O E D)$ quotations attributed to her adult work. ${ }^{1}$ While this article only examines a small selection of words, there are currently over sixty words identifiable in The Double Disguise that predate the OED quotations referencing Edgeworth's adult authorship. Firstly, this article surveys Edgeworth's literary development as a teenager in Ireland, both in terms of reading consumption and narrative production, to explore her experimentation with regional dialect, colloquialisms, and the use of Irish English. ${ }^{2}$ Secondly, while the $O E D$ cites Edgeworth's adult work, it will be shown that it was Edgeworth's linguistic experimentation in her juvenilia helped form her adult writing. Finally, through examining the similarities in word choices and vocabulary between The Double Disguise and her later work, this article argues for the importance of juvenilia on the development of Edgeworth's adult authorship.

The plot of The Double Disguise follows an Irish family staying at the Pig \& Castle Inn on a turnpike road between Liverpool and London. The family consists of Justice Cocoa, a Tipperary grocer who has risen in social standing to become an officer in the Volunteers, his daughter, Dorothea Cocoa (Dolly), ${ }^{3}$ and Fanny, cousin to Dolly. Their host is the Landlady, Mrs Thunder, who is assisted at the Pig \& Castle by her chambermaid, Betty Broom. A final main character, Charles Westbrooke, acts in disguise as two other characters (and gives the play its name), the Fortune Teller and Captain Campbell. There are also several minor roles employed for comic effect or to advance the narrative. The premise of the play is based on Westbrooke testing the earnestness of Dolly as he wishes to make her his wife. Numerous scenes are established where Westbrooke, in disguise, gains access to Dolly, only to witness her avarice and mean-spirited nature on full display. By the end of the play, Westbrooke realises that it is the kind-hearted Fanny who is most deserving of his love.

While The Double Disguise was produced as family entertainment, and only meant for the consumption of those closest to the Edgeworth clan, it signals Edgeworth's turn toward literary realism through a focus on her Anglo-Irish heritage, issues of gender, and representations of the middle and lower classes. This is reflected in The Double Disguise's setting: a common inn providing simple accommodation with much of the plot revolving around the day-to-day running of the lodgings and associated bar. Edgeworth's detailed knowledge of food preparation, travel, and housekeeping, all further the realistic aspects of her juvenilia drama. One other work of Edgeworth's juvenilia is extant: The Mental Thermometer, a clever short story that foreshadows Edgeworth's later didactic tales written specifically for children. It was published in volume 2 of Benjamin Tabart's Juvenile Library, 
1801. In Marilyn Butler's biography of Edgeworth, she argues that "the change in manner between The Mental Thermometer and The Double Disguise is so great that it needs accounting for", ${ }^{4}$ going on to add, "the broad temper of the times was moving writers towards a more frank and detailed realism, and the Edgeworth family's appetite for fact was in itself merely a symptom of this ..." (Butler 153).

Edgeworth's youthful experimentation with realism had a direct influence on the development of the novel. As Walter Allen argues in The English Novel (1958):

Miss Edgeworth occupied new terrirory for the novel. Before her, except when London was the scene, the locale of our fiction had been generalized, conventionalized. Outside London and Bath, the eighteenth-century novelist rarely had a sense of place; the background of his fiction is as bare of scenery almost as an Elizaberthan play; and when landscape came in for its own sake, with Mrs Radcliffe, it was there not because it was a specific landscape but because it was a romantic one. Maria Edgeworth gave fiction a local habitation and a name. And she did more than this: she perceived the relation between the local habitation and the people who dwell in it. She invented, in other words, the Regional Novel, in which the very nature of the novelist's characters is condition, receives its bias and expression, from the fact that they live in a countryside differentiated by a traditional way of life from other countrysides. The region she discovered was Ireland, and, with Ireland, the Irish peasant ... (103)

Yet, while Castle Rackrent has been credited as the first Regional Novel in English, praised for its Irish sketches and representation of the middle and lower classes, Edgeworth inaugurated many of these elements in The Double Disguise. ${ }^{5}$ One of the influences Edgeworth was increasingly drawn to just prior to penning her first surviving drama was French theatre. At the age of fifteen she wrote that "Moliere's [plays] entertained me much. The plots of all I have yet read of Marivaux I think too much alike \& too uninteresting ... the waiting women $\&$ valets are mere machinery to help the author through his plot and to bring their Masters and Mistresses in spite of fate together ..." (Butler 148-150). From a young age Edgeworth recognised that popular French theatre had little interest in providing authentic representations of lower class characters. Indeed, her comment that they were presented as "mere machinery" indicates the extent to which she felt the humanity was stripped from stereotypical "waiting women \& valets".

Once she set her mind to writing, however, Edgeworth chose to give a voice to her characters of a lower social standing in both her juvenilia and her adult authorship. This voice often manifested in characters equipped with an Irish brogue and its origin can be traced to Edgeworth's earliest introduction to Ireland. She was just fourteen years old when she first came into contact with her father's steward, John Langan, whose use of Irish English, and colloquialisms, Edgeworth and her father quickly learned to mimic. In 1834 Edgeworth wrote:

The only character drawn from the life in Castle Rackrent is Thady himself, the teller of the story. He was an old steward (not very old, though, at that time; I added to his age, to allow him time for generations[)]... I heard him when I first came to Ireland, and his dialect struck me, and his character; and I became so acquainted with it, that I could think and speak in it without effort: so that when, for mere amusement, without any ideas of publishing, I began to write a family history as Thady would tell it, he seemed to stand beside me and dictate and I wrote as fast as my pen could go. (Castle Rackrent 86) 
While John Langan was to become the source for Castle Rackrent's narrator, Thady Quirk, and Edgeworth stated that Thady was the only character "drawn from life", she was working as her father's estate manager. This position saw her in close contact with the Irish lowerclasses who worked the land at Edgeworthstown and no doubt gave Edgeworth an advantage when constructing the Irish brogue and choice of vocabulary for her Irish characters. Yet, it would be an understatement to suggest that Langan wasn't the chief model for her Irish avatars. Indeed, prior to Castle Rackrent, mimicry of John Langan's idiolect found a voice in Edgeworth's juvenilia. The Double Disguise includes Edgeworth's first Irish sketch, the character of Justice Cocoa. The character of the Justice was written specifically for Maria's father to perform replete with a decidedly Irish English vocabulary.

An example of the verbal connection identifiable between Castle Rackrent and The Double Disguise can be found in the use of the exclamation "pooh". Although "pooh" is employed in Castle Rackrent the OED doesn't cite the novel in their quotations providing evidence of a particular meaning. The OED's first reference is to Ben Jonson's Every Man out of his Humor from 1600. While Fielding's Tom Jones (1749) and Sterne's Sentimental Journey (1768) are the third and fourth quotation, it is the second, William Congreve's comedic-drama The Double Dealer from 1694 that provides the link to Edgeworth's juvenilia. The $O E D$ defines "pooh" as: "Expressing impatience, contempt, disdain, etc.". From this point a literary progression is traceable from Congreve's The Double Dealer, to Edgeworth's The Double Disguise, and through to Castle Rackrent. While the narrative of The Double Dealer shares little similarity with The Double Disguise, the plot devices and the structure of both dramas share many commonalities. ${ }^{7}$ The influence of The Double Dealer on Edgeworth's juvenilia is unmistakeable including a reference to The Double Dealer's character, Lady Plyant, in The Double Disguise's epilogue. ${ }^{8}$

Even though she borrowed the use of "pooh" from The Doubler Dealer Edgeworth's mimicry of Congreve's exclamation took on two other forms in her juvenilia: "pugh" and "phoo". The $O E D$ cites "pugh" under the same definition as "pooh" - with Henry Fielding's The History of Tom Jones from 1749 providing the first evidence of this particular spelling. Once again Edgeworth is not cited by the $O E D$ as providing evidence of a particular meaning for "pugh" even though she used it extensively in her work. The $O E D$ defines the word "phoo", however, as: "Expressing discomfort, disgust, weariness, or relief", and list Maria Edgeworth's Castle Rackrent as the first record of its use. "Phoo" is employed only once in Castle Rackrent in Sir Condy's line, "What is it you're reading there, my dear? - phoo, I've cut myself with this razor" (44). In The Double Disguise it is used on three separate occasions by Edgeworth's chiefly Irish character, Justice Cocoa, and always in multiples. For example, the Justice delivers the line, "Phoo! Phoo! Phoo! Arrah, now be quiet ..." (69). ${ }^{9}$ The use of "phoo" (and "pooh") in Edgeworth's juvenilia predates its employment in Castle Rackrent by fourteen years.

A further example of Edgeworth's use of Irish English in her juvenilia, which can be found attributed to her adult work in the $O E D$, is the use of the noun "Spalpeen". The $O E D$ cites the etymology of "Spalpeen" as "Irish" and provides three separate definitions of the word. The first definition provided defines the word as: "A common workman or labourer; a farm-worker or harvester". The first quotation for this definition is attributed to Arthur Young and his work A Tour in Ireland from 1780 where he, fancifully, defines the term as: "Connaught labourers; they are called spalpeens: spal, in Irish, is a scythe, and peen a penny; that is, a mower for a penny a day". Yet, there are two other definitions provided for "Spalpeen" - one defines the noun as, "A youngster, a boy" and attributes its first use to Bram Stoker's The Snake's Pass from 1891 and provides the quotation: "I remimber it ... a lot higher up the mountain whin I was a spalpeen". The Snake's Pass focuses on the troubled 
romance between an English tourist and a local Irish peasant. A further quotation from Jane Barlow's, From the Land of the Shamrock (1901), is provided as a second quotation providing evidence of the meaning. The third definition for "Spalpeen", which is in fact the second definition chronologically listed in the $O E D$, is defined as: "Used contemptuously: A low or mean fellow; a scamp, a rascal", and quotes Maria Edgeworth's 1817 Love \& Law from her Comic Dramas as the first evidence of the particular meaning, providing the supporting quotation, "The spalpeen! turned into a buckeen, that would be a squireen,--but can't". Both OED definitions for "buckeen" and "squireen" include supporting quotations from Maria Edgeworth's 1812 novel The Absentee - and in the case of "squireen" Edgeworth is attributed first evidence of the word.

As with Edgeworth's use of "phoo" and "pooh" her employment of "Spalpeen" has precedence in her juvenilia. Again, it is the drama's key Irish character of Justice Cocoa who delivers the line, complete, no doubt, with his heavy Irish brogue: "Why who in the name of the old one have we here? Why who are you, you Sir? What brought you into my daughter's apartment ye spalpeen you?" (The Double Disguise 33). What is most pertinent about Edgeworth's use of "Spalpeen" is that the original influence to use it in The Double Disguise came from Arthur Young and his 1780 work A Tour in Ireland. We know Edgeworth studied Young's work as her fictitious English editor of Castle Rackrent remarked that "Mr. Young's picture of Ireland, in his tour through that country, was the first faithful portrait of its inhabitants" (61). ${ }^{10}$ Inherent in this comment, albeit one provided through the guise of a fictional English editor, is the importance of providing "faithful portraits" of the inhabitants of particular region. For Edgeworth, this was the case even when writing work of fiction. Yet, prior to the rediscovery of the manuscript of The Double Disguise it was thought that Edgeworth had established these Irish terms in her adult work. It was Edgeworth's youthful endeavours as an author, however, where she first experimented with adapting Young's use of "Spalpeen", and Congreve's use of "phoo" to suit her purpose - a use that is only credited to her adult work - yet one that reveals part of Edgeworth's progression as a writer.

Edgeworth's early engagement with regional language can also be witnessed in her use of expressions such as "nigh hand". The $O E D$ defines the use of "nigh hand" as "Near or close at hand; nearby" and notes that it is chiefly Scottish, Irish English, and English regional (north and midlands). The $O E D$ quotes Castle Rackrent's quintessentially Irish glossary note for "fairy mounts". The note, written by the fictitious English editor, quotes an "elderly man" of Irish heritage who states, "There was no house to see any where nigh hand, or any building, or barn, or place at all ... " (69). Throughout the lengthy Glossary note the elderly Irish man continues his use of Irish dialect that the "editor" "translates" for the uninitiated reader. Examples include "fair and easy", translated as "quietly"; "beast", translated as "horse"; "lit", translated as "alighted"; "mind", translated as "recollect" or "know"; and "mote", translated as "barrow".

In the case of Edgeworth's juvenilia written over ten years earlier, however, the use of "nigh hand" was reserved for her English character, the Landlady. The Landlady, the owner of the Pig \& Castle Inn where the action of The Double Disguise takes place, states, "Oh aye, I am always at the Bar, or nigh hand ..." (20). ${ }^{11}$ In having her English character employ the use of "nigh hand" Edgeworth conforms to the OED's "English regional" classification. In fact, as mentioned, the inn in Edgeworth's drama is set on the road between Liverpool and London, placing it squarely in the north/midlands geographical area. Edgeworth did have a habit of using certain aspects of language as a general marker of spoken English, rather than dialectal examples of Irish English, and her use of "nigh hand" appears to be another instance of this. ${ }^{12}$ Rather than employing the term 'nigh hand' as an exclusive marker of Irish language, another way to view Edgeworth's earliest engagement with the phrase would be to consider it as a legacy of her early upbringing in England. This further supports the notion 
that the juvenilia was an important stepping stone for Edgeworth's future influence on the Regional Novel, and of course, the English language. Although she would go on to employ "nigh hand" as an Irish phrase, her experimentation with it in her juvenilia is evident.

Edgeworth's youthful freedom to experiment with regional terms and Irish English was matched by her experimentation with colloquial language. A further $O E D$ quotation providing first evidence of a particular meaning that links Edgeworth's adult authorship with her juvenilia, and once again to a colloquialism, is the term "to shell out". The $O E D$ defines "to shell out" as "To disburse, pay up, hand over". The first quotation providing the first evidence of the word supplied by the $O E D$, "One of you ... must shell out your corianders", is taken from Edgeworth's moral tale, Forester (1801). The OED defines "corianders" as a slang term for "coin, money; short for coriander-seed" and provides Edgeworth's quotation from Forester as the second quotation providing evidence of the particular meaning. This colloquial term, however, has its antecedence in The Double Disguise. The freedom to create a narrative that was heavily imbued with the common language heard by the young Maria around Edgeworthstown once again manifests in a line written for Justice Cocoa. In The Double Disguise the line containing "shell out" occurs when the family, falsely, learns of Dolly's lottery win. In order to celebrate the Justice tells Dolly that he has already given out silver and that she should be gracious enough to give out gold: "If an old fellow like me shelled out all the silver he had, the least you could do would be to shower gold ... " (40).

As with Edgeworth's regionally recognisable phrases, which aided in infusing a selection of Edgeworth's narratives with a distinct sense of place, her employment of colloquialisms and slang furthered the inherent realism in her narratives. The vernacular of the common people, like the use of regional terms and Irish English, created a sense of belonging. ${ }^{13}$ Edgeworth realised that a common language had the ability to bond like-minded individuals and exclude those on the periphery. ${ }^{14}$ Colloquialisms and the use of phrases specific to a regional area, or multiple areas in the case of "nigh hand", goes beyond a simple employment of accent where pronunciation is the only recognisable distinction. Edgeworth's choices of vocabulary, grammar, and pronunciation $^{15}$ led to her realistic and recognisable locales.

A further aspect of Edgeworth's youthful engagement with realistic language is once again reflected in the $O E D$ 's quotations providing evidence for particular meanings. The $O E D$ contains forty-seven evidential quotations referencing Castle Rackrent. Of these forty-seven there are currently nine words in The Double Disguise that predate the OED quotations attributed to Castle Rackrent. ${ }^{16}$ Two of these terms in particular, "Blackamoor" and "Nabob", can be viewed as important signposts of Edgeworth's early interest in the "more frank and detailed realism" that Marilyn Butler argued was identifiable in Edgeworth's The Double Disguise. The term "Blackamoor", with reference to its use in Castle Rackrent, is defined in the $O E D$ as "A black African ... any dark-skinned person", while "Nabob" is defined as, "a British person who acquired a large fortune in India during the period of British rule".

Edgeworth's employment of "Blackamoor" in The Double Disguise carries a slightly different connotation to that quoted in Castle Rackrent. Even so, Edgeworth's use of "Blackamoor" in her juvenilia signals her youthful experimentation with realistic vocabulary. Rather than a reference to a specific person's skin colour, as is the case in Castle Rackrent, the young Edgeworth used the term to describe the "whitewashing" of a room in the inn. The use of Blackamoor in Castle Rackrent occurs in the line, "What will become of him and his, ...with this heretic Blackamore [Lord Rackrent's Jewish wife] at the head of the Castle Rackrent estate ..." (21). In this instance the $O E D$ definition that applies to Edgeworth's particular use of the term is "to wash an Ethiop, a blackamoor (white)". The association between the use of the term in the juvenilia with the use found in Castle Rackrent is selfevident; however, the employment of the term in The Double Disguise is one that reveals a 
minor part of Edgeworth's development as a writer.

Firstly, Edgeworth's employment of "Blackamoor" in the manuscript of The Double Disguise contains two disparate spellings. Edgeworth oscillated between "Blackmoores" and "Blackamores" when using the word in her youthful work. Of course, both iterations are spelled incorrectly. Yet what it shows is Edgeworth's early experimentation with the word, even though she was unsure of the correct spelling, she decided to employ the term in her juvenilia anyway. Secondly, while the use of "Blackamoor" in Castle Rackrent is employed with a different connotation to that in The Double Disguise we can once again witness Edgeworth's early experimentation that would later enter her adult work. Although the employment of "Blackamoor" in The Double Disguise refers to the whitewashing of a room it retains the allusion to a "dark-skinned person" - in this instance to the colloquial phrase for washing them white. One example of this particular use in The Double Disguise is the Landlady's question about a room in the inn, directed at her maid, Betty Broom, "Has Tim Trowell finished white washing the Blackmoore's Head?" (5). ${ }^{17}$

A similar progression is identifiable in the term "Nabob" where we once again witness Edgeworth's early engagement with a particular term being reused in Castle Rackrent. In The Double Disguise's employment of "Nabob" we find Edgeworth's intersection with the contemporary interest in the criminality of the British colonialists in India. ${ }^{18}$ Writers of the period, including Samuel Johnson, wrote about the crimes of the "Nabob". An edition of Boswell's Life of Johnson, which includes selections of Johnson's writing on the "Nabob", was published the same year as Edgeworth wrote The Double Disguise. After disguising himself as the Fortune Teller and Captain Campbell, the character of Westbrooke unveils his true identity and it is revealed that he has amassed a great wealth overseas. Justice Cocoa, the patriarch of the Cocoa family, is concerned when he realises that Westbrooke, who it is assumed wants the Justice's daughter's hand in marriage, may have become wealthy through crimes committed in India. When Westbrooke divulges the legal means of his wealth the Justice states, "I like ye better coming home with your hands clean ... than with the four or five thousand pound in your pocket, a lac of rupees \& the crimes of Nabob" (75).

In Castle Rackrent Edgeworth once again alludes to the possibility of a character being a "Nabob". In describing the newly arrived, and harshly treated, Lady Rackrent (married to Sir Kit Rackrent), Thady states, "I had a great regard for the family... when strange gentlemen's servants came to the house, and would begin to talk about the bride, I took care to put the best foot foremost, and passed her for a Nabob, in the kitchen, which accounted for her dark complexion, and every thing" (22). ${ }^{19}$ Thady describes Lady Rackrent to the servants as a "Nabob" while knowing that she is of Jewish heritage. In both The Double Disguise and Castle Rackrent Edgeworth never goes beyond the allusion to a character of hers being an actual Nabob. This is also the case in Edgeworth's The Patronage (1814), where once again an allusion to the "Nabob" is made, yet no direct characterisation is provided. Yet, clearly, her literary progression is once again identifiable in the inclusion of this term in both her juvenilia and her adult novel.

One final example the $O E D$ quotes from Castle Rackrent, which once again preexisted in The Double Disguise further highlights the importance of Edgeworth's earliest engagement with the Irish English she encountered on her arrival in Ireland. Under the main definition for "do", and the sub-definition of "Expressing habitual action or state", the $O E D$ provides the definition "Irish English. As an auxiliary to be and a present participle, forming a durative habitual present tense" to define the use of "do be". ${ }^{20}$ Edgeworth's quotation from Castle Rackrent, "Nay, don't be denying it, Judy, for I think the better of ye for it", however, is provided not as an example of "do be", but as the OED states, "Quot. 1800 [Castle Rackrent], which shows sense $31 \mathrm{~b}$ rather than habitual action, perhaps points to the origin of the present construction in Irish English". 
Sense $31 \mathrm{~b}$ is defined as "Forming the negative imperative with not as negator. Also with a second personal pronoun preceding the main verb (now only following the contracted form don't)". In this instance, Thady's employment of "don't be" in Castle Rackrent is said to have been the origin of the Irish English durative habitual present tense "do be". It is once again, unsurprisingly, the Irish character of Justice Cocoa who delivers the line in The Double Disguise, "Lookee now friend, don't be making your games upon me" (69). The employment of "don't be" in The Double Disguise marks Edgeworth's earliest surviving example of its use in her writing. And although we witness another example of Edgeworth's erroneous spelling in her use of "Lookee" in this sentence, it is, in fact, a further indicator of the Irish English voicing she bestowed upon on the character of Justice Cocoa. "Lookey" is defined in the OED as (Irish English) "Used to draw or direct attention; 'see', 'observe', 'take note'". Once again, we observe Edgeworth's early experimentation with language informing her adult work.

Edgeworth's freedom to produce colloquialisms and regional terms can be contributed to the private nature of the production and performance of The Double Disguise. The drama was written prior to Edgeworth becoming a famous published author and Maria and her father never intended the work to be released to the public. The private nature of The Double Disguise allowed for an openness in Edgeworth's style that would have otherwise needed to be constrained. A short note Richard Lovell Edgeworth wrote to his trusted friend Erasmus Darwin supports the assertion that the work was produced as a private production. Richard Lovell wrote of The Double Disguise: "We have just been acting a little farce, for our own family and intimate visitors only. The piece written, and all the characters filled, by ourselves" (The Double Disguise xx). The radical nature of the dialogue contained within The Double Disguise meant that it was unsuitable as Edgeworth's first major publication. By the time she was a published author, however, she had borrowed so heavily from both the characterisations and language in The Double Disguise that some of her later work could have appeared derivative. $^{21}$

Maria Edgeworth's early engagement with authors such as Arthur Young and William Congreve were to have a lasting influence on the language development in her narratives. As was her youthful introduction to Ireland and her interactions with the Edgeworthstown steward, John Langan. The early mimicry of the intriguing characters she met while working as the estate manager on her father's property proved to be crucial in the early development of Edgeworth's characterisation of the lower classes. Since the age of fifteen, when she had been disheartened by the "mere machinery" of the "waiting women \& valets" of French theatre, Edgeworth had a drive to provide her fictional characters with an enhanced level of realism, and to ensure that they were afforded a recognisable voice - one with a definable location. While Edgeworth would return to her juvenilia as an established author, both with relation to language use, and to wider narrative techniques such as plot and characterisation, ${ }^{22}$ the similarities in the word choices and vocabulary between The Double Disguise and Edgeworth's adult work examined in this article are a further indication of the seminal nature of her earliest surviving drama.

\section{Notes}

\footnotetext{
${ }^{1}$ Written and performed in 1786, The Double Disguise is Edgeworth's first surviving drama. It sat unpublished in the Bodleian Library at Oxford until 2014.

${ }^{2}$ Throughout this essay I employ the OED's categories of Irish English, Regional, and Colloquial as cited in the dictionary.
} 
${ }^{3}$ A link between The Double Disguise and Edgeworth's later drama, The Lottery, published in The Parent's Assistant in 1804, is evident when juxtaposing two of the central characters, both of who are named Dolly. Dolly in The Lottery turns out to be just as covetous and callous as her eponymous counterpart from The Double Disguise. In both narratives, Edgeworth employed the name "Dolly" as a label for her undesirable characters; the Oxford English Dictionary defines Dolly as "A drab, slattern, useless woman". Both The Double Disguise and The Lottery also employ the use of a lottery ticket that is analogous with a desire to rise in social status through any means. See: Ryan Twomey. 'The Child Is Father of the Man': The Importance of Juvenilia in the Development of the Author. Houten: Hes \& De Graaf, 2012. pp. 31-7.

${ }^{4}$ For a further examination of The Mental Thermometer see: Maria Edgeworth, The Double Disguise. Eds. Christine Alexander and Ryan Twomey. Sydney: Juvenilia Press, 2014. pp. xvii-xix.

${ }^{5}$ See Twomey, 'The Child Is Father of the Man': The Importance of Juvenilia in the Development of the Author. pp. 19-52.

${ }^{6}$ It is used once in Castle Rackrent, p. 49, and twice in The Double Disguise, p. 8, p. 44.

${ }^{7}$ For an examination of these commonalities see The Double Disguise, pp. xxx-xxxiii

${ }^{8}$ Ibid. p. 79

9 The $O E D$ defines “Arrah” as “An expletive expressing emotion or excitement, common in Anglo-Irish speech".

${ }^{10}$ For a discussion of the fictitious "English editor" of the novel see my preface to the Norton Critical Edition of Castle Rackrent, pp. vi-x.

${ }^{11}$ The $O E D$ defines "Aye" as "(a) Ever, always, continually; (b) at all times, on all occasions".

12 See: Ryan Twomey, "Experimenting with Home: Maria Edgeworth and the Development of the Regional Tale". Eds. David Owen and Lesley Peterson. Home and Away: The Place of the Child Writer. Cambridge: Cambridge Scholars, 2015, p. 88.

${ }^{13}$ For a deeper examination of the use of Irish English as an identity marker, see Claire Norris, "The Big House: Space, Place, and Identity in Irish Fiction". New Hibernia Review 8. 1 (2004): 107-121.

${ }^{14}$ This was one of the reasons that Maria and her father decided to include a glossary for Castle Rackrent. See note 18 above.

15 This is often called eye-dialect, where nonstandard spelling for speech is used to draw attention to pronunciation. For an examination of Edgeworth's use of this technique see: "Experimenting with Home: Maria Edgeworth and the Development of the Regional Tale", pp. 79-93.

${ }^{16}$ In addition to "nigh hand", these are "Better", "Blackamoor", "Do", "Law", "Lay", "Manufacture", "Nabob", and "Right".

${ }^{17}$ Infelicities, such as spelling and grammar mistakes, are a common occurrence in juvenilia.

${ }^{18}$ See: James Boswell, Life of Johnson, v.5. Ed. George Birkbeck Hill. London: Henry Baldwin, 1786, p. 120.

${ }^{19}$ This is also the quotation provided by the $O E D$.

${ }^{20}$ For a closer examination of "do be" in Irish English, see Patricia Ronan. "Irish English Habitual Do Be Revisited". Linguaculture 1 (2010): 43-55.

${ }^{21}$ See Ryan Twomey. “For 'Family and Intimate Visitors Only': The Influence of Maria Edgeworth's Juvenilia on the Production of her Adult Dramas". Bookbird 55, 2 (2017): 10-19.

${ }^{22}$ See ibid., and, "Experimenting with Home: Maria Edgeworth and the Development of Regional Dialect".

\section{Works Cited}

Allen, Walter Ernest. The English Novel: A Short Critical History. Harmondsworth: Penguin, 1958.

Boswell, James. Life of Samuel Johnson, v. 5. Ed. George Birkbeck Hill. London: Henry Baldwin, 1786.

Brewer, Charlotte. "First Quotations". $22 \quad$ September 2018. http://oed.hertford.ox.ac.uk/main/content/view/403/451/
"Role
of Quotations".
22
September
2018.

http://oed.hertford.ox.ac.uk/main/content/section/12/187/index.html

. "The Oxford English Dictionary's Treatment of Female-Authored Sources of the Eighteenth Century". Current Issues in Late Modern English. Eds. Ingrid Tieken-

Boon van Osatde and Wim van der Wurff. Bern: Peter Lang, 2009. 209-238.

Butler, Marilyn. Maria Edgeworth: A Literary Biography. Oxford: Clarendon Press, 1972. 
Edgeworth, Maria. Castle Rackrent. Norton Critical Edition. Ed. Ryan Twomey. New York: Norton, 2014.

. The Double Disguise. Eds. Christine Alexander and Ryan Twomey. Sydney: Juvenilia Press, 2014.

Norris, Claire. "The Big House: Space, Place, and Identity in Irish Fiction". New Hibernia Review 8.1 (2004): 107-121.

Ronan, Patricia. "Irish English Gabitual Do Be Revisited". Linguaculture 1 (2010): 43-55.

Twomey, Ryan. "Experimenting with Home: Maria Edgeworth and the Development of the Regional Tale". Home and Away: The Place of the Child Writer. Eds. David Owen and Lesley Peterson. Newcastle: Cambridge Scholars, 2015. 81-93.

"The Child is Father of the Man": The Imporatnce of Juvenilia in the Development of the Author. Houten: Hes and De Graaf, 2012.

- "For 'Family and Intimate Visitors Only': The Influence of Maria Edgeworth's Juvenilia on the Production of her Adult Dramas". Bookbird 55.2 (2017): 10-19.

Received: 5 November $2018 \quad$ Revised version accepted: 18 February 2019

Ryan Twomey is a senior lecturer at Macquarie University in Sydney Australia. He is the editor of the Norton Critical Edition of Maria Edgeworth's Castle Rackrent, and co-editor of her juvenilia drama The Double Disguise (Juvenilia Press, University of New South Wales). In addition to this editorial work, Dr Twomey has published widely on the early writing of Edgeworth and the influence this writing had on her adult authorship.

ryan.twomey@mq.edu.au 